\title{
Prehospital Stroke Care: Limitations of Current Interventions and Focus on New Developments
}

\author{
Laetitia Yperzeele ${ }^{a, c}$ Robbert-Jan Van Hooff ${ }^{a, c}$ Ann De Smedt ${ }^{a, c}$ \\ Alexis Valenzuela Espinoza ${ }^{c}$ Rohny Van de Casseye ${ }^{e}$ Ives Hubloue ${ }^{b, d}$ \\ Jacques De Keyser ${ }^{a, c, f}$ Raf Brouns ${ }^{a, c}$ \\ Departments of a Neurology and ${ }^{b}$ Emergency Medicine, Universitair Ziekenhuis Brussel, and ${ }^{c}$ Center for \\ Neurosciences (C4N) and ${ }^{\mathrm{d}}$ Research Group on Emergency and Disaster Medicine (ReGEDiM), Vrije Universiteit \\ Brussel (VUB), Brussels, and ' $F$ Flanders District of Creativity, Leuven, Belgium; ' Department of Neurology, \\ University Medical Center Groningen, University of Groningen, Groningen, The Netherlands
}

\section{Key Words}

Stroke management . Acute stroke $\cdot$ Telemedicine

\begin{abstract}
Background: The global burden of stroke is immense, both in medical and economic terms. With the aging population and the ongoing industrialization of the third world, stroke prevalence is expected to increase and will have a major effect on national health expenditures. Currently, the medical treatment for acute ischemic stroke is limited to intravenous recombinant tissue plasminogen activator (IV r-tPA), but its time dependency leads to low utilization rates in routine clinical practice. Prehospital delay contributes significantly to delayed or missed treatment opportunities in acute stroke. State-of-the-art acute stroke care, starting in the prehospital phase, could thereby reduce the disease burden and its enormous financial costs. Summary: The first part of this review focuses on current education measures for the general public, the emergency medical services (EMS) dispatchers and paramedics. Although much has been expect-
\end{abstract}

ed of these measures to improve stroke care, no major effects on prehospital delay or missed treatment opportunities have been demonstrated over the years. Most interventional studies showed little or no effect on the onset-to-door time, IV r-tPA utilization rates or outcome, except for prenotification of the receiving hospital by the EMS. No data are currently available on the cost-effectiveness of these commonly used measures. In the second part, we discuss new developments for the improvement of prehospital stroke diagnosis and treatment which could open new perspectives in the nearby future. These include the implementation of prehospital telestroke and the deployment of mobile stroke units. These approaches may improve patient care and could serve as a platform for prehospital clinical trials. Other opportunities include the implementation of noninvasive diagnostics (like transcranial ultrasound and blood-borne biomarkers) and the reevaluation of neuroprotective strategies in the prehospital phase. Key Messages: Timely initiation of treatment can effectively reduce the

L.Y. and R.-J.V.H. contributed equally and share first authorship.

\section{KARGER}

E-Mail karger@karger.com www.karger.com/ced
(C) 2014 S. Karger AG, Basel

1015-9770/14/0381-0001\$39.50/0
Laetitia Yperzeele, MD

Department of Neurology

Universitair Ziekenhuis Brussel

Laarbeeklaan 101, BE-1090 Brussels (Belgium)

E-Mail laetitiayperzeele@ outlook.be 
medical and economic burden of stroke and should begin with optimal prehospital stroke care. For this, prehospital telemedicine is a particularly attractive approach because it is a scalable solution that has the potential to rapidly optimize acute stroke care at limited cost.

(c) 2014 S. Karger AG, Basel

\section{Introduction to Acute Stroke Care}

Timely treatment can effectively reduce the medical and economic burden of stroke and should begin in the prehospital phase.

\section{Time is Brain}

Rapid reperfusion of the occluded blood vessel and protection of viable but vulnerable nervous tissue in the penumbra are the two cornerstones of acute stroke therapy. The current medical treatment for acute ischemic stroke is limited to intravenous recombinant tissue plasminogen activator (IV r-tPA), but its time dependency leads to low utilization rates in routine clinical practice. International guidelines stipulate that treatment should be initiated within $4.5 \mathrm{~h}$ after symptom onset, yet even within this time window efficacy decreases dramatically with time, while the risk of complications increases [1,2].

\section{Competence is Brain}

Stroke patients treated in specialized stroke units run by trained and dedicated personnel have better outcomes $[3,4]$. All types of patients appear to benefit from stroke unit care [5-7] and this approach is cost-effective [8]. The European Stroke Organisation (ESO) and the American Stroke Association (ASA) recommend the immediate admission of patients with acute stroke in a stroke unit and the incorporation of a stroke unit as part of the continuum of stroke care $[3,9]$.

\section{Prehospital Stroke Care}

The slogans 'time is brain' and 'competence is brain' adequately point out that acute stroke is a time-critical medical emergency requiring specialized treatment. This view has largely been adopted for in-hospital patient care, but data from stroke-specific prehospital clinical trials are limited.

The primary goals of emergency medical services (EMS) for patients with suspected stroke are rapid evaluation, early stabilization, concise neurological evaluation, and quick transport and triage to the nearest medical center with a stroke unit that can provide ultra-early treatment [9-11].
In this review we aim to systematically describe the pitfalls and limitations of current prehospital strategies to reduce treatment delays. We also focus on new developments for the improvement of prehospital stroke diagnosis and we discuss therapeutic opportunities which could open new perspectives in the nearby future.

\section{Current Strategies to Reduce Treatment Delay}

\section{Public Education}

Delay in seeking medical attention after the onset of stroke symptoms often leads to missed treatment opportunities [12]. Factors influencing care-seeking behavior include psychological, cognitive, clinical, social and demographic factors [13, 14]. Multimedia campaigns generally improve stroke symptom knowledge and have been found to influence calls to EMS for stroke [15], but knowledge and awareness rapidly decrease in the months after the intervention [16]. Continuous advertising would therefore be necessary to sustain a beneficial effect. Also, these campaigns mainly target the general public and often fail to reach important risk populations [17-19]. Moreover, improved symptom awareness does not necessarily lead to increased care-seeking behavior $[20,21]$ and may not reduce prehospital delay or an increase in thrombolysis rates. A number of single-center studies have reported increased r-tPA treatment rates after public awareness campaigns, but these increases are difficult to attribute to these campaigns only as they were combined with multifaceted interventions such as the introduction of code stroke protocols or regionalization of stroke care [22-24]. Finally, solid evidence on the long-term effect of these interventions is lacking, as are data on their costeffectiveness.

\section{Education of EMS Dispatchers and Paramedics}

Early identification of stroke patients by dispatchers and EMS is pivotal for rapid transport to an appropriate treatment facility. EMS dispatchers may use tools and protocols for screening via phone interview, including the Medical Priority Dispatch System [25], the Cincinnati Prehospital Stroke Scale (CPSS) [26], the FaceArm-Speech test (FAST) [27] and the modified Los Angeles Prehospital Stroke Screen [28]. Paramedics arriving on scene are recommended to use prehospital stroke scales for the assessment of potential stroke patients. These screening tools are considered useful, despite their limited sensitivity and specificity. For instance, the false-negative rate of the CPSS and the FAST is about 
$24-33 \%[26,27,29]$. Studies assessing the impact of these scales on transport times and treatment rates are nonexistent.

\section{Prehospital Stroke Code Activation and Priority Transport}

Priority transport to centers with adequate stroke care facilities after prehospital stroke code activation is mandatory to improve onset-to-door times. Patients transported by EMS have higher probability to arrive within 2 $\mathrm{h}$ of stroke onset [30], are more often treated with IV rtPA and have better outcome [31]. Data from the Hyper Acute STroke Alarm study showed a significant increase in thrombolysis frequency and a shorter time to the stroke unit for patients with higher prehospital priority level [32]. EMS should prenotify the receiving hospital to allow in-hospital activation of the stroke protocol and mobilization of the stroke team. This reduces door-to-imaging times [33], but the effect on the door-to-needle time varies between studies [34]. Prehospital notification increases IV r-tPA administration rates by $3.2-44 \%[10,35-38]$.

\section{Summary}

Despite major efforts, prehospital delays for stroke patients have not reduced significantly over the years [39]. Most interventional studies showed little or no effect on the onset-to-door time, r-tPA utilization rates or outcome, except for prenotification of the receiving hospital by the EMS [10, 30, 31, 35-38]. The team of Meretoja et al. [40] forms an exception; they were able to achieve median door-to-needle times of about 20 min thanks to redesigning their stroke pathways. The majority of these studies applied a pre- and postintervention design and only few randomized trials have been performed. Finally, there is no data available on the cost-effectiveness of these commonly used measures.

\section{New Developments and Future Concepts}

\section{Telestroke}

Misdiagnosis and late recognition of stroke symptoms contribute to prehospital delay and admission to inadequate clinical facilities [41]. Telestroke can bring stroke expertise to underserved geographical areas [10, 42-44] and may help solve the shortage of stroke experts [45-47] by allowing remote assessment of stroke patients via audio-video conference and by assisting local physicians in the decision-making process for acute stroke [41]. Pursuant to ongoing technological developments and in line with the ASA and the ESO guidelines, the implementation of telestroke for optimizing in-hospital stroke care is currently applied in several countries [48-54].

A large number of studies have shown that telestroke is a valid, accurate and reliable tool that can be used to improve stroke outcome $[46,54]$ and telestroke networking potentially increases the likelihood of treatment with IV r-tPA [10, 54-56]. The economic issues remain to be fully explored, but recent findings suggest that a telestroke network offers multiple benefits beyond thrombolysis [53]. It may increase the number of patients discharged home and reduce the costs borne by the network hospitals [57]. Treatment with IV r-tPA is clearly cost-effective [58, 59] and telestroke is promising to be cost-effective too, both from a hospital network point of view [57] and from a society point of view $[60,61]$.

Most telestroke programs are organized according to the 'hub and spoke' model (fig. 1a), in which a specialized center (the 'hub') delivers its knowledge to one or more smaller hospitals (the 'spokes'). Technological requirements include a remote-control camera, high-resolution monitors and two-way full-motion video and audio teleconferencing [62]. The initial applications of telemedicine for stroke were hospital-based 'point-to-point models' over landlines (Telestroke 1.0; fig. 1b). The next generation of telestroke systems (Telestroke 2.0) used World Wide Web-based technology [63, 64], permitting consultations to be conducted from anywhere at any time (fig. 1c) and therefore leading to faster response and potentially shorter onset-to-treatment times. One of the main drawbacks lies in limited availability of high-speed internet with sufficient bandwidth [45]. Whereas 'Telestroke 1.0 and 2.0' were hospital-based systems aiming to provide stroke expertise to hospitals without stroke-oriented professional healthcare, 'Telestroke 3.0' brings telestroke to the prehospital arena (fig. 1d). Research on prehospital telestroke systems is recommended by the ASA, as it may facilitate early stroke diagnosis, the assessment of stroke severity and the selection of patients for specific stroke treatments [46].

\section{Prehospital Telestroke}

The experience with prehospital telemedicine for the assessment of stroke severity, however, is limited. Projects using bidirectional audio-video communication for real-time evaluation of patients on-site or during emergency transport are scarce, even though systems incorporating video consultation have been demonstrated to result in more accurate decision making compared to teleconsultation by telephone alone [65-67]. The TeleBAT project $[50,51]$ relied on mobile technology with limited 
Fig. 1. a The 'hub and spoke' model connects several 'spoke' hospitals to 1 'hub'. Evolution of telemedicine applications for stroke starting from point-to-point communication over landlines between fixed workstations (Telestroke 1.0; b) over mobile telemedicine consultation using the World Wide Web (Telestroke 2.0; c) to prehospital telestroke care (Telestroke 3.0; d).

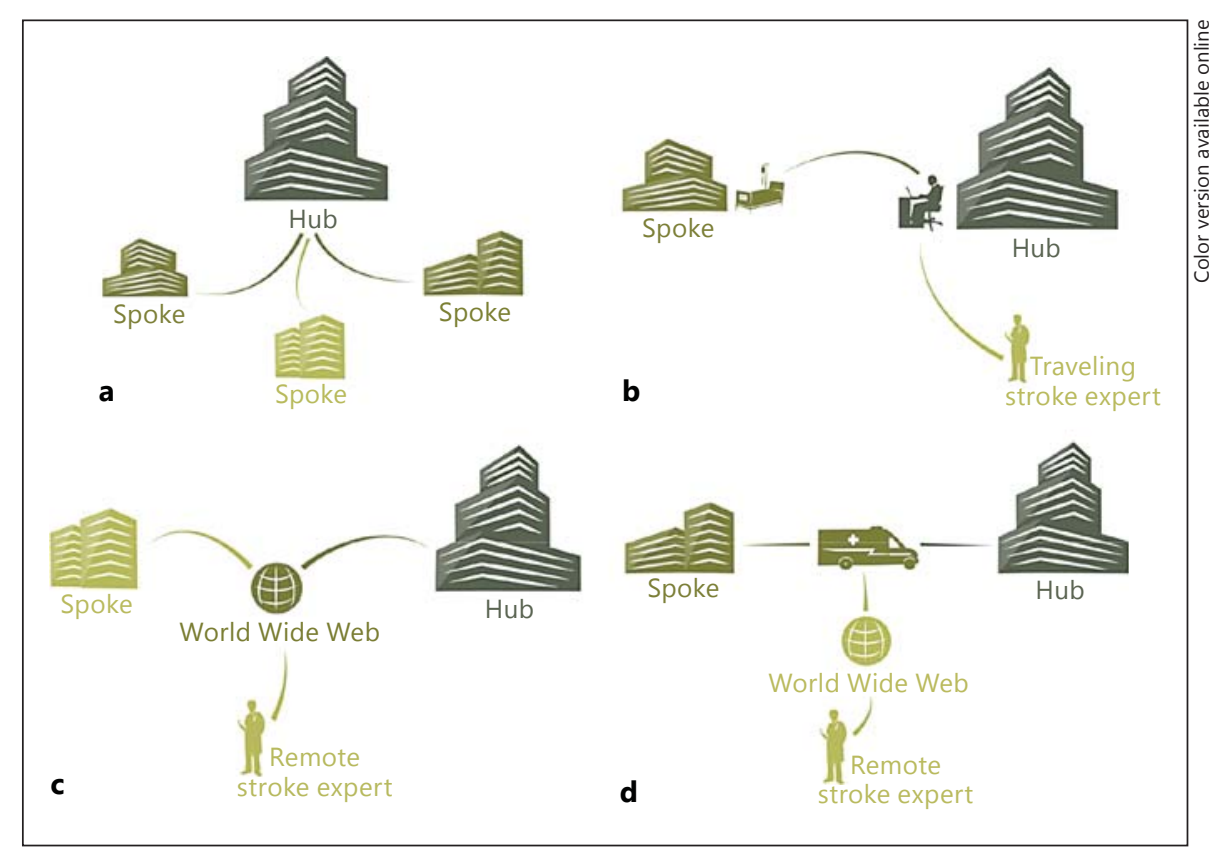

bandwidth and unstable connectivity, which completely precluded real-time conferencing. Liman et al. [68] deemed $3 \mathrm{G}$ connectivity to be unacceptable for clinical use because adequate assessment was possible in only $40 \%$ of the scenarios. The Aachen project [69] is currently the only project that investigated real-time prehospital telemedicine in stroke patients as opposed to healthy volunteers mimicking stroke scenarios. Broadband communication via parallelized data channels was used to mitigate the effects of unstable connectivity and dropouts, but technical instability of video transmission during ambulance transportation remained an issue. A difference in prehospital time intervals or superiority to prehospital EMS diagnosis was not proven, although the small study population could account for this. In a follow-up study, the researchers upgraded to second- and third-generation mobile networks and used roof antennas which increased video transmission performance, but stable transmission was not obtained in all cases [70]. Fourth-generation technology using ultra-broadband internet access may overcome these limitations. The Prehospital Stroke Study at the UZ Brussel (PreSSUB) showed promising results using $4 \mathrm{G}$ technology in healthy volunteers and allowed a more feasible and reliable assessment [71]. Although some technical issues like competition with other users for high-speed broadband access still remain to be resolved, prioritized connection for medical services could be one of the possibilities.
Standardized evaluation of stroke severity is pivotal for adequate treatment decision making. The National Institutes of Health Stroke Scale (NIHSS) is the current gold standard for bedside practice and for remote assessment by telemedicine. Even though widely used, this scale suffers from several drawbacks for use in telestroke, which inspired researchers to develop more adapted alternatives, among them being the Unassisted TeleStroke Scale $[71,72]$. This scale has been shown to be a simple, quantitative measure for the evaluation of stroke severity through telemedicine, without the assistance of a third party and with a time gain of 5 min compared to the NIHSS. We have no knowledge of scales other than the NIHSS and the UTSS being tested in prehospital telemedicine to quantify neurological impairment. Scales used by (para)medics on-site to estimate prehospital probability of acute stroke could also be implemented for telestroke but lack information about stroke severity, which is important for therapeutic decision making.

Prehospital telestroke is a very promising concept, facilitating specialized stroke care in the very early stage based on integration of bidirectional audiovisual communication with point-of-care laboratory analysis, vitals and decision support software. To allow breakthrough results, several issues still need to be tackled, including data security, privacy, medical device regulations, liability on product failure and reimbursement $[44,73]$. 


\section{Mobile Stroke Units}

An alternative view to reduce the delay to stroke treatment involves the deployment of highly specialized ambulances and stroke teams for prehospital stroke care. This approach has been evaluated in two pilot studies. Walter et al. [74] were the first to dispatch a 'mobile stroke unit' (MSU), consisting of a sizable ambulance with integrated CT scanner, point-of-care laboratory and a device for teleconsultation with the hospital neuroradiologist. The MSU is equipped with an expert team consisting of a paramedic and a physician trained in stroke medicine and is dispatched together with the standard emergency support system. Data from CT scans or real-time video of clinical examination of patients were transmitted via High-Speed Downlink Packet Access. MSU care was associated with a significant reduction in the time from alarm to treatment decision compared to optimized conventional stroke treatment, but this did not result in a higher number of patients receiving thrombolytic therapy or in improved neurological outcome [74]. The deployment of a stroke emergency mobile unit (STEMO) has been tested in the Pre-Hospital Acute Neurological Treatment and Optimization of Medical Care in Stroke (PHANTOM-S) study [75]. Similar to the MSU, the STEMO was equipped with a neurologist, a radiologist, a paramedic, a CT scanner, a point-of-care laboratory, and a teleradiology system. Prehospital diagnostics were performed on-site or in the STEMO. Images of a CT brain scan were sent to a radiologist on call via a teleconsultation system using a $3 \mathrm{G}$ connection. In contrast to the MSU, the PHANTOM-S study was conducted in a densely populated area and a radiologist was present in the STEMO. This study showed that it is feasible and safe to identify acute stroke patients and to administer thrombolytics in the prehospital arena. Moreover, this intervention was associated with a significant reduction of the call-to-needle time compared to controls [75]. However, scalability and radiation legislation limit the widespread application of this strategy. The price tag of integrating CT scans into emergency vehicles and the staffing costs for the accompanying highly trained personnel are likely to limit wide implementation. Data on the cost-effectiveness of this approach are currently lacking.

\section{Prehospital Transcranial Ultrasound}

Being noninvasive, nonradiating and less expensive than other imaging techniques, ultrasound has been evaluated in the prehospital setting in various conditions [7678]. Its feasibility was firstly documented in the Regensburg stroke mobile project [77]. Several drawbacks cur- rently limit the implementation of this technique. Firstly, the use of $2-\mathrm{mHz}$ transcranial Doppler and duplex should be validated for cloth localization. Secondly, the use of contrast agents to enhance sensitivity of ultrasound devices is currently not approved in the USA. Thirdly, the value of pulsatility monitoring to discern hemorrhagic presentations would need to be explored. Fourthly, scanning protocols would need to be established and validated. Finally, a trained sonographer would be required onsite. As currently very few practitioners have developed skills in transcranial ultrasound, this limits the generalizability of this approach.

\section{Blood-Borne Biomarkers}

The diagnostic and prognostic value of numerous biochemical substances reflecting various aspects of the ischemic cascade have been studied [79], but until now no biomarker with sufficient specificity and sensitivity has been identified to justify its use in routine clinical practice. Measurement of E-selectin and resistin have shown additive value to traditional risk factors [80]. Plasma glial fibrillary acid protein analysis has shown the ability to differentiate intracranial hemorrhage and ischemic stroke within $4.5 \mathrm{~h}$ of symptom onset, and point-of-care systems could be useful in the prehospital phase [81]. The identification of biomarkers with adequate diagnostic accuracy, which can readily be measured with limited cost, could prove to be a major breakthrough in acute stroke management.

\section{Neuroprotective Strategies}

Despite showing efficacy in experimental models, the concept of neuroprotection has failed in clinical trials. Several reasons have been identified for the translational difficulties faced by the numerous neuroprotective strategies tested over the last two decades, but delayed initiation of the treatment has been a major contributor in the overwhelming majority of trials [82]. Because the beneficial effects of neuroprotection are likely to be more pronounced if initiated early, it is reasonable to reexamine the most promising agents in the prehospital phase of acute stroke.

The Field Administration of Stroke Therapy - Magnesium (FAST-MAG) trial puts this approach to test. This ongoing phase III neuroprotection trial evaluates the effectiveness and safety of field-initiated magnesium sulfate in improving the long-term functional outcome of patients with acute stroke [83]. Magnesium acts as a natural calcium blocker and may therefore inhibit or delay calcium-mediated ischemic cell death during and after cere- 
Table 1. Overview of new developments for improvement of prehospital stroke care

\begin{tabular}{|c|c|c|c|}
\hline Approach & Research projects & Features & Challenges \\
\hline $\begin{array}{l}\text { Prehospital } \\
\text { telestroke }\end{array}$ & $\begin{array}{l}\text { TeleBAT }[50,51] \\
\text { Liman et al. }[68] \\
\text { Aachen project [69] } \\
\text { PreSSUB [71] }\end{array}$ & $\begin{array}{l}\text { Bidirectional audio communication } \\
\text { Uni-or bidirectional video communication } \\
\text { Real-time clinical evaluation } \\
\text { Real-time transmission of vital parameters } \\
\text { Prearrival notification } \\
\text { Relatively low implementation cost } \\
\text { Stroke history checklist (Aachen project) } \\
\text { ECG transmission (Aachen project) } \\
\text { Independent of location consultant (PreSSUB) }\end{array}$ & $\begin{array}{l}\text { Dependence on mobile internet connection } \\
\text { No brain imaging prior to arrival at hospital } \\
\text { Data on time-to-treatment decision are not yet } \\
\quad \text { available } \\
\text { Diagnostic superiority to standard care is not yet } \\
\quad \text { established }\end{array}$ \\
\hline MSU & $\begin{array}{l}\text { MSU [74] } \\
\text { STEMO [75] }\end{array}$ & $\begin{array}{l}\text { On-site presence of physician trained in stroke } \\
\text { Integrated CT scan and point-of-care laboratory } \\
\text { Teleneuroradiology or radiologist on site } \\
\text { Reduction of time-to-treatment decision has been } \\
\quad \text { demonstrated }\end{array}$ & $\begin{array}{l}\text { Lack of scalability with high implementation cost } \\
\text { Specialized staff required on-site at all times } \\
\text { Radiation legislation } \\
\text { Access to } 3 G \text { required for teleradiology } \\
\text { Real-time images are not available } \\
\text { Increased r-tPA utilization or improved outcome } \\
\quad \text { remains to be demonstrated }\end{array}$ \\
\hline $\begin{array}{l}\text { Prehospital } \\
\text { trans-cranial } \\
\text { ultrasound }\end{array}$ & $\begin{array}{l}\text { Regensburg project } \\
\text { [77] }\end{array}$ & $\begin{array}{l}\text { Noninvasive and nonradiating imaging } \\
\text { Low implementation cost } \\
\text { Diagnosis of middle cerebral artery occlusion }\end{array}$ & $\begin{array}{l}\text { Trained neurosonographer required on site } \\
\text { Validation studies are required } \\
\text { Contrast agents are not widely approved }\end{array}$ \\
\hline $\begin{array}{l}\text { Blood-borne } \\
\text { biomarkers }\end{array}$ & $\begin{array}{l}\text { Glial fibrillary acid } \\
\text { protein }[81]\end{array}$ & $\begin{array}{l}\text { Differentiation between ischemic and hemorrhagic } \\
\text { stroke is plausible }\end{array}$ & $\begin{array}{l}\text { Low sensitivity and specificity } \\
\text { Point-of-care system unavailable } \\
\text { Not yet evaluated in the prehospital setting }\end{array}$ \\
\hline $\begin{array}{l}\text { Neuroprotective } \\
\text { strategies }\end{array}$ & $\begin{array}{l}\text { FAST-MAG [83] } \\
\text { Minocycline [85] }\end{array}$ & $\begin{array}{l}\text { Possible neuroprotective effects } \\
\text { Reassuring safety profile }\end{array}$ & $\begin{array}{l}\text { Early administration is mandatory } \\
\text { Data from FAST-MAG are not yet available } \\
\text { Minocycline has not been shown to be efficacious }\end{array}$ \\
\hline
\end{tabular}

bral ischemic events [84]. Very early initiation of neuroprotective support could help to preserve the penumbra until recanalization therapy can be started [83].

Agents targeting inflammation, like minocycline, may also prove to be beneficial as neuroprotective agents. In a recent pilot study the use of intravenous-administered minocycline in a small sample of acute ischemic and hemorrhagic stroke patients has proven to be safe but not efficacious [85], although scalability and a relative delay in administration (within $24 \mathrm{~h}$ after onset) could account for this.

\section{Potential Impact of New Developments}

The new strategies described above hold the potential to improve patient outcome as they may reduce the time to stroke care by initiating the diagnostic and the therapeutic processes already on-site or during ambulance transportation. These approaches may also augment the rate of thrombolytic therapy and improve patient selection for advanced treatment in specialized centers. Further, prehospital telestroke and MSU are uniquely situated as platforms for the administration of neuroprotective agents very early in the prehospital phase, aiming to preserve the penumbra while awaiting recanalization therapy [83]. This would offer ample opportunity to boost research in this field, including expedited administration of (new) therapies, enhancement of inclusion rates, facilitation of informed consent procedures, and improved overall research quality thanks to real-time involvement of stroke experts and post hoc case reviewing using recordings of the telestroke consultations [47]. Hypothermia, statins, minocycline, magnesium sulfate and albumin are examples of neuroprotective treatments that could make suitable candidates for prehospital clinical trials supported by emergency telestroke consultation or MSU. The advantages and disadvantages of these new developments are summarized in table 1.

\section{Conclusion}

The concepts 'time is brain' and 'competence is brain' have shifted the focus of acute stroke care to providing specialized support already in the prehospital arena. Education-based programs have been demonstrated to be insufficient in reducing missed treatment opportunities. 
Much is expected from prehospital telemedicine, which opens new perspectives and may allow continuous guidance by a stroke specialist throughout the acute stroke care continuum. Deployment of MSU could be an alternative in densely populated regions with ample access to highly trained caregivers and without stringent budgetary restrictions. Other opportunities include the implementation of noninvasive diagnostics, reevaluation of neuroprotective strategies and improved quality of clinical trials in the prehospital setting.

\section{Disclosure Statement}

Laetitia Yperzeele, Robbert-Jan van Hooff, Rohny Van de Casseye, Ives Hubloue and Jacques De Keyser report no disclosures. Alexis Valenzuela Espinoza is a researcher at the Center for Neurosciences funded by the Brussels Institute for Research and Innovation (INNOVIRIS). Ann De Smedt is a research assistant at the Fund for Scientific Research Flanders (FWO). Raf Brouns is a Senior Clinical Investigator of the Research Foundation - Flanders (Belgium) and has received consultancy or speaker honoraria from Pfizer, Medtronic, Shire Human Genetics Therapies, SanofiAventis, Boehringer-Ingelheim and Bayer. No funding was received for this study.

\section{References}

1 Hacke W, Donnan G, Fieschi C, Kaste M, von Kummer R, Broderick JP, Brott T, Frankel M, Grotta JC, Haley EC Jr, Kwiatkowski T, Levine SR, Lewandowski C, Lu M, Lyden P, Marler JR, Patel S, Tilley BC, Albers G, Bluhmki E, Wilhelm M, Hamilton S: Association of outcome with early stroke treatment: pooled analysis of ATLANTIS, ECASS, and NINDS rt-PA stroke trials. Lancet 2004;363: 768-774.

2 Hacke W, Kaste M, Bluhmki E, Brozman M, Davalos A, Guidetti D, Larrue V, Lees KR, Medeghri Z, Machnig T, Schneider D, von Kummer R, Wahlgren N, Toni D: Thrombolysis with alteplase 3 to 4.5 hours after acute ischemic stroke. New Engl J Med 2008;359: 1317-1329.

-3 Schwamm LH, Pancioli A, Acker JE 3rd, Goldstein LB, Zorowitz RD, Shephard TJ, Moyer P, Gorman M, Johnston SC, Duncan PW, Gorelick P, Frank J, Stranne SK, Smith R, Federspiel W, Horton KB, Magnis E, Adams RJ: Recommendations for the establishment of stroke systems of care: recommendations from the American Stroke Association's Task Force on the Development of Stroke Systems. Stroke 2005;36:690-703.

-4 Sulter G, Elting JW, Langedijk M, Maurits NM, De Keyser J: Admitting acute ischemic stroke patients to a stroke care monitoring unit versus a conventional stroke unit: a randomized pilot study. Stroke 2003;34:101-104.

5 How do stroke units improve patient outcomes? A collaborative systematic review of the randomized trials. Stroke Unit Trialists Collaboration. Stroke 1997;28:2139-2144.

-6 Seenan P, Long M, Langhorne P: Stroke units in their natural habitat: systematic review of observational studies. Stroke 2007;38:18861892.

-7 Saposnik G, Kapral MK, Coutts SB, Fang J, Demchuk AM, Hill MD: Do all age groups benefit from organized inpatient stroke care? Stroke 2009;40:3321-3327.
8 Patel A, Knapp M, Perez I, Evans A, Kalra L: Alternative strategies for stroke care: cost-effectiveness and cost-utility analyses from a prospective randomized controlled trial. Stroke 2004;35:196-203.

-9 Guidelines for management of ischaemic stroke and transient ischaemic attack 2008. Cerebrovasc Dis 2008;25:457-507.

10 Jauch EC, Saver JL, Adams HP Jr, Bruno A, Connors JJ, Demaerschalk BM, Khatri P, McMullan PW Jr, Qureshi AI, Rosenfield K, Scott PA, Summers DR, Wang DZ, Wintermark M, Yonas H: Guidelines for the early management of patients with acute ischemic stroke: a guideline for healthcare professionals from the American Heart Association/ American Stroke Association. Stroke 2013;44: 870-947.

-11 Adams HP Jr, del Zoppo G, Alberts MJ, Bhatt DL, Brass L, Furlan A, Grubb RL, Higashida RT, Jauch EC, Kidwell C, Lyden PD, Morgenstern LB, Qureshi AI, Rosenwasser RH, Scott PA, Wijdicks EF: Guidelines for the early management of adults with ischemic stroke. Stroke 2007;38:1655-1711.

12 Howard VJ, Lackland DT, Lichtman JH, McClure LA, Howard G, Wagner L, Pulley L, Gomez CR: Care seeking after stroke symptoms. Ann Neurol 2008;63:466-472.

13 Moser DK, Kimble LP, Alberts MJ, Alonzo A, Croft JB, Dracup K, Evenson KR, Go AS, Hand MM, Kothari RU, Mensah GA, Morris DL, Pancioli AM, Riegel B, Zerwic JJ: Reducing delay in seeking treatment by patients with acute coronary syndrome and stroke. Circulation 2006;114:168-182.

14 Becker K, Fruin M, Gooding T, Tirschwell D, Love P, Mankowski T: Community-based education improves stroke knowledge. Cerebrovasc Dis 2001;11:34-43.

15 Bray JE, Mosley I, Bailey M, Barger B, Bladin C: Stroke public awareness campaigns have increased ambulance dispatches for stroke in Melbourne, Australia. Stroke 2011;42:21542157.
Hodgson C, Lindsay P, Rubini F: Can mass media influence emergency department visits for stroke? Stroke 2007;38:2115-2122.

17 Marx JJ, Gube C, Faldum A, Kuntze H, Nedelmann M, Haertle B, Dieterich M, Eicke BM: An educational multimedia campaign improves stroke knowledge and risk perception in different stroke risk groups. Eur J Neurol 2009; 16:612-618.

18 Miyamatsu N, Kimura K, Okamura T, Iguchi Y, Nakayama $H$, Toyota A, Watanabe $M$, Morimoto A, Morinaga M, Yamaguchi T: Effects of public education by television on knowledge of early stroke symptoms among a Japanese population aged 40 to 74 years: a controlled study. Stroke 2012;43:545-549.

19 Addo J, Ayis S, Leon J, Rudd AG, McKevitt C, Wolfe CD: Delay in presentation after an acute stroke in a multiethnic population in South London: the South London stroke register. J Am Heart Assoc 2012;1:e001685.

20 Marx JJ, Nedelmann M, Haertle B, Dieterich M, Eicke BM: An educational multimedia campaign has differential effects on public stroke knowledge and care-seeking behavior. J Neurol 2008;255:378-384.

21 Lecouturier J, Rodgers H, Murtagh MJ, White M, Ford GA, Thomson RG: Systematic review of mass media interventions designed to improve public recognition of stroke symptoms, emergency response and early treatment. BMC Public Health 2010;10:784.

22 Barsan WG, Brott TG, Broderick JP, Haley EC Jr, Levy DE, Marler JR: Urgent therapy for acute stroke. Effects of a stroke trial on untreated patients. Stroke 1994;25:2132-2137.

23 Morgenstern LB, Staub L, Chan W, Wein TH, Bartholomew LK, King M, Felberg RA, Burgin WS, Groff J, Hickenbottom SL, Saldin K, Demchuk AM, Kalra A, Dhingra A, Grotta JC: Improving delivery of acute stroke therapy: the TLL Temple Foundation Stroke Project. Stroke 2002;33:160-166. 
-24 Morgenstern LB, Bartholomew LK, Grotta JC, Staub L, King M, Chan W: Sustained benefit of a community and professional intervention to increase acute stroke therapy. Arch Int Med 2003;163:2198-2202.

-25 Buck BH, Starkman S, Eckstein M, Kidwell CS, Haines J, Huang R, Colby D, Saver JL: Dispatcher recognition of stroke using the national academy medical priority dispatch system. Stroke 2009;40:2027-2030.

26 Kothari RU, Pancioli A, Liu T, Brott T, Broderick J: Cincinnati prehospital stroke scale: reproducibility and validity. Ann Emerg Med 1999;33:373-378.

27 Harbison J, Hossain O, Jenkinson D, Davis J, Louw SJ, Ford GA: Diagnostic accuracy of stroke referrals from primary care, emergency room physicians, and ambulance staff using the face arm speech test. Stroke 2003;34:7176.

28 Kidwell CS, Starkman S, Eckstein M, Weems $\mathrm{K}$, Saver JL: Identifying stroke in the field. Prospective validation of the Los Angeles Prehospital Stroke Screen (LAPSS). Stroke 2000; 31:71-76.

29 Studnek JR, Asimos A, Dodds J, Swanson D: Assessing the validity of the Cincinnati prehospital stroke scale and the medic prehospital assessment for code stroke in an urban emergency medical services agency. Prehosp Emerg Care 2013;17:348-353.

- 30 Rose KM, Rosamond WD, Huston SL, Murphy CV, Tegeler $\mathrm{CH}$ : Predictors of time from hospital arrival to initial brain-imaging among suspected stroke patients: the North Carolina Collaborative Stroke Registry. Stroke 2008;39:3262-3267.

- 31 de la Ossa NP, Sanchez-Ojanguren J, Palomeras E, Millan M, Arenillas JF, Dorado L, Guerrero C, Abilleira S, Davalos A: Influence of the stroke code activation source on the outcome of acute ischemic stroke patients. Neurology 2008;70:1238-1243.

- 32 Berglund A, Svensson L, Sjostrand C, von Arbin $M$, von Euler M, Wahlgren N, Engerstrom L, Hojeberg B, Kall TB, Mjornheim S, Engqvist A: Higher prehospital priority level of stroke improves thrombolysis frequency and time to stroke unit: the Hyper Acute Stroke Alarm (HASTA) study. Stroke 2012;43:2666-2670.

- 33 Patel MD, Rose KM, O’Brien EC, Rosamond WD: Prehospital notification by emergency medical services reduces delays in stroke evaluation: findings from the North Carolina Stroke Care Collaborative. Stroke 2011;42: 2263-2268.

34 Fassbender K, Balucani C, Walter S, Levine SR, Haass A, Grotta J: Streamlining of prehospital stroke management: the golden hour. Lancet Neurol 2013;12:585-596.

-35 McKinney JS, Mylavarapu K, Lane J, Roberts V, Ohman-Strickland P, Merlin MA: Hospital prenotification of stroke patients by emergency medical services improves stroke time targets. J Stroke Cerebrovasc Dis 2013;22:113118.
36 Abdullah AR, Smith EE, Biddinger PD, Kalenderian D, Schwamm LH: Advance hospital notification by EMS in acute stroke is associated with shorter door-to-computed tomography time and increased likelihood of administration of tissue-plasminogen activator. Prehosp Emerg Care 2008;12:426-431.

37 Kim SK, Lee SY, Bae HJ, Lee YS, Kim SY, Kang MJ, Cha JK: Pre-hospital notification reduced the door-to-needle time for IV t-PA in acute ischaemic stroke. Eur J Neurol 2009; 16:1331-1335.

38 Baldereschi M, Piccardi B, Di Carlo A, Lucente G, Guidetti D, Consoli D, Provinciali L, Toni D, Sacchetti ML, Polizzi BM, Inzitari D: Relevance of prehospital stroke code activation for acute treatment measures in stroke care: a review. Cerebrovasc Dis 2012;34:182190.

-39 Tong D, Reeves MJ, Hernandez AF, Zhao X, Olson DM, Fonarow GC, Schwamm LH, Smith EE: Times from symptom onset to hospital arrival in the Get with the Guidelines Stroke Program 2002 to 2009: temporal trends and implications. Stroke 2012;43: 1912-1917.

40 Meretoja A, Strbian D, Mustanoja S, Tatlisumak T, Lindsberg PJ, Kaste M: Reducing inhospital delay to 20 minutes in stroke thrombolysis. Neurology 2012;79:306-313.

-41 Audebert HJ, Schwamm L: Telestroke: scientific results. Cerebrovasc Dis 2009;27(suppl 4):15-20

$\checkmark 42$ Hess DC, Wang S, Gross H, Nichols FT, Hall CE, Adams RJ: Telestroke: extending stroke expertise into underserved areas. Lancet Neurol 2006;5:275-278.

43 Demaerschalk BM: Telemedicine or telephone consultation in patients with acute stroke. Curr Neurol Neurosci Rep 2011;11: 42-51.

44 Aita MC, Nguyen K, Bacon R, Capuzzi KM: Obstacles and solutions in the implementation of telestroke: billing, licensing, and legislation. Stroke 2013;44:3602-3606.

45 Schwamm LH, Holloway RG, Amarenco P, Audebert HJ, Bakas T, Chumbler NR, Handschu R, Jauch EC, Knight WAt, Levine SR, Mayberg M, Meyer BC, Meyers PM, Skalabrin E, Wechsler LR: A review of the evidence for the use of telemedicine within stroke systems of care. Stroke 2009;40:2616-2634.

46 Schwamm LH, Audebert HJ, Amarenco P, Chumbler NR, Frankel MR, George MG, Gorelick PB, Horton KB, Kaste M, Lackland DT, Levine SR, Meyer BC, Meyers PM, Patterson V, Stranne SK, White CJ: Recommendations for the implementation of telemedicine within stroke systems of care. Stroke 2009;40:2635-2660.

47 Henninger N, Chowdhury N, Fisher M, Moonis M: Use of telemedicine to increase thrombolysis and advance care in acute ischemic stroke. Cerebrovasc Dis 2009;27(suppl 4):914.
48 Hess DC, Audebert HJ: The history and future of telestroke. Nat Rev Neurol 2013;9: 340-350.

49 Rubin MN, Wellik KE, Channer DD, Demaerschalk BM: A systematic review of telestroke. Postgrad Med 2013;125:45-50

-50 LaMonte MP, Cullen J, Gagliano DM, Gunawardane $\mathrm{R}, \mathrm{Hu} \mathrm{P}$, Mackenzie $\mathrm{C}$, Xiao $\mathrm{Y}$ : TeleBAT: mobile telemedicine for the brain attack team. J Stroke Cerebrovasc Dis 2000;9: 128-135

51 LaMonte MP, Xiao Y, Hu PF, Gagliano DM, Bahouth MN, Gunawardane RD, MacKenzie CF, Gaasch WR, Cullen J: Shortening time to stroke treatment using ambulance telemedicine: TeleBAT. J Stroke Cerebrovasc Dis 2004; 13:148-154.

52 Audebert HJ, Tietz V, Boy S, Pilz P, Haberl RL, Schenkel J: Acceptance of telemedicine for acute stroke care. The German project TEMPIS. Nervenarzt 2009;80:184-189.

53 Tatlisumak T, Soinila S, Kaste M: Telestroke networking offers multiple benefits beyond thrombolysis. Cerebrovasc Dis 2009;27(suppl 4):21-27.

54 Sairanen T, Soinila S, Nikkanen M, Rantanen K, Mustanoja S, Farkkila M, Pieninkeroinen I, Numminen H, Baumann P, Valpas J, Kuha T, Kaste M, Tatlisumak T: Two years of Finnish telestroke: thrombolysis at spokes equal to that at the hub. Neurology 2011;76:1145-1152.

55 Audebert HJ, Kukla C, Vatankhah B, Gotzler B, Schenkel J, Hofer S, Furst A, Haberl RL: Comparison of tissue plasminogen activator administration management between telestroke network hospitals and academic stroke centers: the Telemedical Pilot Project for Integrative Stroke Care in Bavaria/Germany. Stroke 2006;37:1822-1827.

56 Vatankhah B, Schenkel J, Furst A, Haberl RL Audebert HJ: Telemedically provided stroke expertise beyond normal working hours. The Telemedical Project for Integrative Stroke Care. Cerebrovasc Dis 2008;25:332-337.

57 Switzer JA, Demaerschalk BM, Xie J, Fan L, Villa KF, Wu EQ: Cost-effectiveness of huband-spoke telestroke networks for the management of acute ischemic stroke from the hospitals' perspectives. Circ Cardiovasc Qual Outcomes 2013;6:18-26

-58 Tung CE, Win SS, Lansberg MG: Cost-effectiveness of tissue-type plasminogen activator in the 3- to 4.5-hour time window for acute ischemic stroke. Stroke 2011;42:2257-2262.

-59 Fagan SC, Morgenstern LB, Petitta A, Ward RE, Tilley BC, Marler JR, Levine SR, Broderick JP, Kwiatkowski TG, Frankel M, Brott TG, Walker MD: Cost-effectiveness of tissue plasminogen activator for acute ischemic stroke. NINDS rt-PA stroke study group. Neurology 1998;50:883-890.

60 Nelson RE, Saltzman GM, Skalabrin EJ, Demaerschalk BM, Majersik JJ: The cost-effectiveness of telestroke in the treatment of acute ischemic stroke. Neurology 2011;77:15901598. 
61 Demaerschalk BM, Switzer JA, Xie J, Fan L, Villa KF, Wu EQ: Cost utility of hub-andspoke telestroke networks from societal perspective. Am J Manag Care 2013;19:976-985.

-62 Medeiros de Bustos E, Vuillier F, Chavot D, Moulin T: Telemedicine in stroke: organizing a network - rationale and baseline principles. Cerebrovasc Dis 2009;27(suppl 4):1-8.

63 Levine SR, Gorman M: 'Telestroke': the application of telemedicine for stroke. Stroke 1999;30:464-469.

-64 Switzer JA, Levine SR, Hess DC: Telestroke 10 years later-'telestroke 2.0'. Cerebrovasc Dis 2009;28:323-330.

65 Meyer BC, Raman R, Hemmen T, Obler R, Zivin JA, Rao R, Thomas RG, Lyden PD: Efficacy of site-independent telemedicine in the STRokE DOC trial: a randomised, blinded, prospective study. Lancet Neurol 2008;7:787795.

66 Capampangan DJ, Wellik KE, Bobrow BJ, Aguilar MI, Ingall TJ, Kiernan TE, Wingerchuk DM, Demaerschalk BM: Telemedicine versus telephone for remote emergency stroke consultations: a critically appraised topic. Neurologist 2009;15:163-166.

67 Demaerschalk BM, Raman R, Ernstrom K, Meyer BC: Efficacy of telemedicine for stroke: pooled analysis of the Stroke Team Remote Evaluation Using a Digital Observation Camera (STRokE DOC) and STRokE DOC Arizona telestroke trials. Telemed J e-Health 2012;18:230-237.

-68 Liman TG, Winter B, Waldschmidt C, Zerbe N, Hufnagl P, Audebert HJ, Endres M: Telestroke ambulances in prehospital stroke management: concept and pilot feasibility study. Stroke 2012;43:2086-2090.

- 69 Bergrath S, Reich A, Rossaint R, Rortgen D, Gerber J, Fischermann H, Beckers SK, Brokmann JC, Schulz JB, Leber C, Fitzner C, Skorning M: Feasibility of prehospital teleconsultation in acute stroke-a pilot study in clinical routine. PloS One 2012;7:e36796.

70 Bergrath S, Czaplik M, Rossaint R, Hirsch F, Beckers SK, Valentin B, Wielputz D, Schneiders MT, Brokmann JC: Implementation phase of a multicentre prehospital telemedicine system to support paramedics: feasibility and possible limitations. Scand J Trauma Resusc Emerg Med 2013;21:54.

71 Van Hooff RJ, Cambron M, Van Dyck R, De Smedt A, Moens M, Espinoza AV, Van de Casseye R, Convents A, Hubloue I, De Keyser J, Brouns R: Prehospital unassisted assessment of stroke severity using telemedicine: a feasibility study. Stroke 2013;44:2907-2909.

72 Van Hooff RJ, De Smedt A, De Raedt S, Moens M, Marien P, Paquier P, De Keyser J, Brouns R: Unassisted assessment of stroke severity using telemedicine. Stroke 2013;44: 1249-1255.

73 Medeiros de Bustos E, Moulin T, Audebert $\mathrm{HJ}$ : Barriers, legal issues, limitations and ongoing questions in telemedicine applied to stroke. Cerebrovasc Dis 2009;27(suppl 4):3639.

74 Walter S, Kostopoulos P, Haass A, Keller I, Lesmeister M, Schlechtriemen T, Roth C, Papanagiotou P, Grunwald I, Schumacher $\mathrm{H}$, Helwig S, Viera J, Korner H, Alexandrou M, Yilmaz U, Ziegler K, Schmidt K, Dabew R, Kubulus D, Liu Y, Volk T, Kronfeld K, Ruckes C, Bertsch T, Reith W, Fassbender K: Diagnosis and treatment of patients with stroke in a mobile stroke unit versus in hospital: a randomised controlled trial. Lancet Neurol 2012; 11:397-404.

75 Weber JE, Ebinger M, Rozanski M, Waldschmidt C, Wendt M, Winter B, Kellner P, Baumann A, Fiebach JB, Villringer K, Kaczmarek S, Endres M, Audebert HJ: Prehospital thrombolysis in acute stroke: results of the PHANTOM-S pilot study. Neurology 2013; 80:163-168.

76 Holscher T, Dunford JV, Schlachetzki F, Boy S, Hemmen T, Meyer BC, Serra J, Powers J, Voie A: Prehospital stroke diagnosis and treatment in ambulances and helicopters - a concept paper. Am J Emerg Med 2013;31 743-747.

77 Schlachetzki F, Herzberg M, Holscher T, Ertl M, Zimmermann M, Ittner KP, Pels H, Bogdahn U, Boy S: Transcranial ultrasound from diagnosis to early stroke treatment. Part 2. Prehospital neurosonography in patients with acute stroke: the Regensburg stroke mobile project. Cerebrovasc Dis 2012;33:262271.

78 Holscher T, Schlachetzki F, Zimmermann M, Jakob W, Ittner KP, Haslberger J, Bogdahn U, Boy S: Transcranial ultrasound from diagnosis to early stroke treatment. 1. Feasibility of prehospital cerebrovascular assessment. Cerebrovasc Dis 2008;26:659-663.

79 Brouns R, De Deyn PP: The complexity of neurobiological processes in acute ischemic stroke. Clin Neurol Neurosurg 2009;111:483495.

80 Prugger C, Luc G, Haas B, Morange PE, Ferrieres J, Amouyel P, Kee F, Ducimetiere P, Empana JP: Multiple biomarkers for the prediction of ischemic stroke: the PRIME study. Arterioscler Thromb Vasc Biol 2013;33:659666.

81 Foerch C, Niessner M, Back T, Bauerle M, De Marchis GM, Ferbert A, Grehl H, Hamann GF, Jacobs A, Kastrup A, Klimpe S, Palm F, Thomalla G, Worthmann H, Sitzer M: Diagnostic accuracy of plasma glial fibrillary acidic protein for differentiating intracerebral hemorrhage and cerebral ischemia in patients with symptoms of acute stroke. Clin Chem 2012;58:237-245.

82 Ginsberg MD: Current status of neuroprotection for cerebral ischemia: synoptic overview. Stroke 2009;40:S111-S114.

83 Field Administration of Stroke Therapy Magnesium (FAST-MAG) trial. 2012. Http:// clinicaltrials.Gov/ct2/show/nct00059332 (accessed March 11, 2014).

84 Westermaier T, Stetter C, Kunze E, Willner N, Raslan F, Vince GH, Ernestus RI: Magnesium treatment for neuroprotection in ischemic diseases of the brain. Exp Transl Stroke Med 2013;5:6.

85 Kohler E, Prentice DA, Bates TR, Hankey GJ, Claxton A, van Heerden J, Blacker D: Intravenous minocycline in acute stroke: a randomized, controlled pilot study and meta-analysis. Stroke 2013;44:2493-2499. 